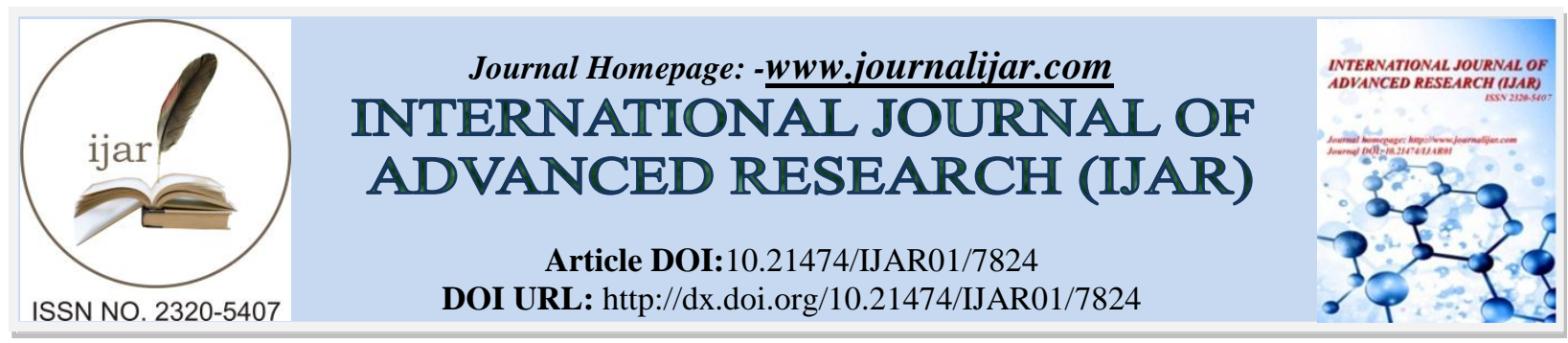

RESEARCH ARTICLE

\title{
INFECTION CONTROL IN DENTAL PRACTICE: REVIEW LITETATURE.
}

\author{
Dr. Ranjeet Dhonkal, B. D. S, Dr. Urvashi Rai, M. D. S, Dr. Divyashree Chaubey, B. D. S and Dr. Soma M. D. \\ 1. Private Practitioner, H.S.Dental Clinic, Dewas, M.P., India. \\ 2. Postgraduate student, Dept. of Prosthodontics, Govt. Dental College and Hospital, Ahmedabad, Gujrat, India. \\ 3. Private Practitioner, Chaubey Dental Clinic, Banglore, Karnataka, India. \\ 4. Counsaltant, Supra Tech Micro Path Laboratory and Research Institute Pvt. Ltd., Indore, M.P., India.
}

\section{Manuscript Info}

\section{Manuscript History}

Received: 6 August 2018

Final Accepted: 8 September 2018

Published: October 2018

Keywords:-

Infection control, Infectious disease,

Dental clinic, Sterilization, Waste

management.

\section{Abstract}

Cross infection control is an essential aspect of dental practice. Assuming that all patients are carrier of disease, strict infection control should be done using universal standard precaution.This can be achieved by wholesome efforts of whole dental team. The purpose of this study is to upgrade our knowledge and highlight the preventive protocol to be followed in dental clinic and laboratory.

Copy Right, IJAR, 2018,. All rights reserved.

\section{Introduction:-}

Cross infection is defined as the transfer of micro-organism like bacteria and viruses between patient and health care professional (HCP) in working area. The infection can transfer between individuals, or through instruments. ${ }^{1,2} \mathrm{Cross}$ infection control has grabed the attention of HCP since the human immunodeficiency virus (HIV) was discovered. In dental practice it is assumed that all patients are carrier of infectious diseases ${ }^{3}$ and dental professionals are at constant risk of exposure to various blood borne und upper respiratory tract pathogens or infectious agents through blood, saliva, aerosol and various other body fluids. ${ }^{4-7}$ Infections can spread in dental setup either through touch, spatter, flying debris or aerosol from the oral cavity. ${ }^{4-6,8-10}$ Accidental exposure to blood borne pathogens can be from the HIV, Hepatitis B virus (HBV), Hepatitis C virus, Mycobacterium tuberculosis, Herpes simplex virus type I and type II, staphylococci, and other potentially infectious agents. ${ }^{7}$ The primary route of accidental exposure by "blood borne pathogens," is mainly due to unintentional percutaneous injuries. The incidence of these types of injuries are more prevalent in dental setups because of high number of patients, frequent patient movement on dental chair, small operating field and various sharp cutting edge instruments being used in dental practice. There are strict infection control guidelines to maintain aseptic condition in clinical and surgical working area recommended by World Health Organization (WHO), ${ }^{11}$ British Medical Association, ${ }^{12}$ British Dental Association. ${ }^{13}$

There are the following basic practices are needed to avoid in dental setups:

1. Immunization of health care workers

2. Evaluation of the patients

3. Personal protection

4. Sterilization

5. Disinfection

Above mention practices are elaborated below in detail
6. Standard precautions

7. Laboratory asepsis

8. Waste management

9. Spillage management

10. Precaution in dental radiology 


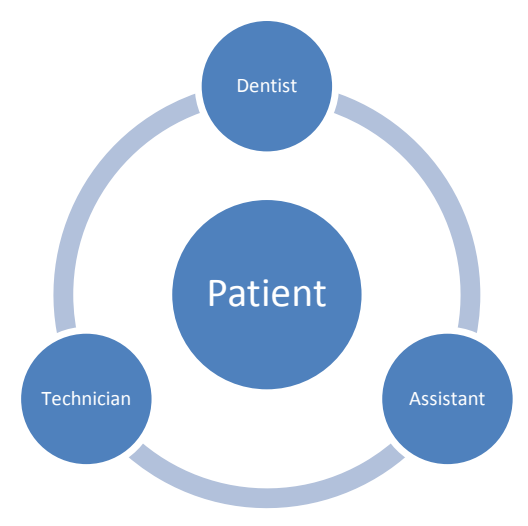

Immunization of health care workers.

Hepatitis B virus (HBV) is well recognized occupational risk for HCP. HBV is very highly infectious, far more than HIV. Any instrument or procedure that can convey minute traces of infected blood as little as $0.00001 \mathrm{ml}$ can be infectious. ${ }^{14}$ ThroughBloodborne pathogens (HBV, HCV) in dental setup, HCP can face some serious complication although the incidence are rare. Incidence of accidental exposure is related to the prevalence of virus in patients, nature and frequency of contact with blood and body fluids through percutaneous or per mucosal route of exposure. ${ }^{15}$ Transmission of HBV can only be occur when either acute or chronic infected patient's blood or body fluid is exposed to HCP. Patient with HBsAg-positive are the carrier and can transmit the infection, \{over 350 million people are carrier worldwide and about 45 million are in India which is second largest only next to china, ${ }^{14}$ \} and utmost attention should be given to prevent the transmission in HCP while performing patient care. Immunization against hepatitis can prevent infection to $\mathrm{HCP}$ specially in dental setup and it will substantially reduce the number of HCP susceptible to these diseases and potential for disease transmission to other HCP and patients. ${ }^{16}$,

${ }^{17}$ Hence, immunization is the most important part of prevention and infection-control for HCP. The schedule for immunization are three doses of 0,1 and 6 month and a booster dose after every 5 years. Of course standard precautions should not be neglected.

\section{Evaluation of patient}

A through medical history should be recorded from every patient in OPD (outpatient department) and should updated at every recall. While history taking, practitioner should diagnose the infectious disease of concern and relevant questions should be asked in detail and diagnose the patient who are either high susceptible to infection or who are potential carrier of the disease. ${ }^{1}$ The most common routes of transmission of infection are as follow

1. Direct contact (e.g. blood)

2. Indirect contact (e.g. instrument, impression)

3. Contact of oral mucosa in infected person

4. Inhalation.

Effective application of infection-control strategies will interrupt the links in chain of transmission.

\section{Personal protection}

Personal hygiene of the staff member who are either directly or indirectly comes in contact with patient should be carefully monitored. In any healthcare setting hand hygiene is the single most important activity for preventing the spread of infection. Hand hygiene must be performed before and after every episode of patient contactHand hygiene is the most cost effective and easy to perform practice which can reduce potential pathogens on the hands and is considered the critical measure for reducing the risk of transmitting organisms to patients and health care professionals. ${ }^{18-21}$ Mild antiseptic like 3\% PCMX (p-chloro, meta-nylenole), povidone iodine or chlorhexidine containing hand cleansers should be preferred. Fingers are the most common vehicle of infection transmission. ${ }^{22,23}$ A clean sink should be use for hand washing, tap should be foot elbow or sensor operated. Finger nails should be short, no jewellery should be worn at the time of operative procedure, cuts or bruises should be covered with bandage as it is serve as easy portal to the infections. Hand piece, three way syringe, and ultra-sonic scaler forms droplets of water, saliva, blood, microorganism and debris. Aerosol can be suspended in air and can be inhaled. ${ }^{24}$ Use of rubber dams ${ }^{25}$ and high velocity air evacuation should be encouraged as it minimizes the disseminationof droplets, spatter and aerosol. ${ }^{26}$ Use of personal protective equipment mainly protect the skin and the mucous 
membranes of the eyes, nose and mouth from exposure to blood or body fluids. Personal protective equipment used in oral health-care settings includes gloves, surgical masks, protective eyewear, face shields, and protective clothing (e.g. gowns and jackets). ${ }^{27,}{ }^{28}$ Reusable PPE (e.g. clinician or patient protective eyewear and face shields) should be disinfectedregularly, according to the manufacturer's directions. OSHA (Occupational Safety and Health Administration) regulations clearly specify that, prior to all treatment procedure all clinical personal must wear gloves and gloves must meet Food and Drug Administration (FDA) regulations.

\section{Needle Stick injuries:}

The risk of infection may be due to percutaneous injury (e.g. a needle stick or cut with a sharp object) or contact of mucous membrane or non-intact skin e.g., abraded skin with blood or other body fluids that are potentially infectious. The risk of sero-conversion post sharps injury, blood or body fluid exposure from a source will depend on

1. The status of the source

2. Type of injury and

3. The status of the victim.

Avoid recapping of needle with both hand, while recapping needles a single handed 'bayonet technique' should be used or resheathing device should be used. Always either remove the burs from hand piece or face away from hand or body.

Instruments are categorized according to Spaulding classification system as critical, semi-critical, or noncritical, on the basis of potential risk for infection associated with their desired application. ${ }^{29,30}$ The biological indicators (spore strips of Bacillus stearotheromophillus) must be checked for every sterilization cycle and if not then at least once in a week with physical and chemicals methods of monitoring of sterilization cycles. Maintain the record of all these monitoring systems. Proper transportation and processing of contaminated critical and semi-critical instruments, proper receiving, cleaning, decontamination, proper packaging, selection of right sterilization method should be done in order to maintain the sterility and disinfection of various instruments.

\section{Sterilization}

Methods For Sterilizing And Disinfecting Patient-Care Items And Environmental Surfaces 28

\begin{tabular}{|c|c|c|c|c|}
\hline Process & Result & Method & Examples & Patient Care Items \\
\hline \multirow[t]{3}{*}{ Sterilization } & \multirow[t]{3}{*}{$\begin{array}{l}\text { Destroys all micro-organisms, } \\
\text { including bacterial spores. }\end{array}$} & $\begin{array}{l}\text { Heat- } \\
\text { automated, } \\
\text { high } \\
\text { temperature }\end{array}$ & Steam, dry heat, unsaturated chemical vapor & $\begin{array}{l}\text { Heat-tolerant critical } \\
\text { and semicritical }\end{array}$ \\
\hline & & $\begin{array}{l}\text { Heat- } \\
\text { automated, } \\
\text { low } \\
\text { temperature }\end{array}$ & Ethylene oxide gas, plasma sterilization & \multirow[t]{2}{*}{$\begin{array}{l}\text { Heat-sensitive } \\
\text { critical and } \\
\text { semicritical }\end{array}$} \\
\hline & & $\begin{array}{l}\text { Liquid } \\
\text { immersion }\end{array}$ & $\begin{array}{l}\text { Glutaraldehyde, glutaraldehydes with phenols, } \\
\text { hydrogen peroxide, hydrogen peroxide with } \\
\text { peracetic acid, peracetic acid }\end{array}$ & \\
\hline \multirow[t]{2}{*}{$\begin{array}{l}\text { High-level } \\
\text { disinfection }\end{array}$} & \multirow{2}{*}{$\begin{array}{l}\text { Destroys all micro-organisms, } \\
\text { but not necessarily high } \\
\text { numbers of bacterial spores. }\end{array}$} & $\begin{array}{l}\text { Heat- } \\
\text { automated }\end{array}$ & Washer disinfector & \multirow[t]{2}{*}{$\begin{array}{l}\text { Heat-sensitive } \\
\text { semicritical }\end{array}$} \\
\hline & & $\begin{array}{l}\text { Liquid } \\
\text { immersion }\end{array}$ & $\begin{array}{l}\text { Glutaraldehyde, glutaraldehydes with phenols, } \\
\text { hydrogen peroxide, hydrogen peroxide with } \\
\text { peracetic acid, ortho-phthalaldehyde }\end{array}$ & \\
\hline $\begin{array}{l}\text { Intermediate- } \\
\text { level } \\
\text { disinfection }\end{array}$ & $\begin{array}{l}\text { Destroys vegetative bacteria } \\
\text { and most fungi and viruses. } \\
\text { Inactivates Mycobacterium } \\
\text { bovis }+ \text {. Not necessarily capable } \\
\text { of killing bacterial spores. }\end{array}$ & $\begin{array}{l}\text { Liquid } \\
\text { contact }\end{array}$ & $\begin{array}{l}\text { EPA-registered hospital disinfectant with label } \\
\text { claim of tuberculocidal activity }\end{array}$ & $\begin{array}{l}\text { Noncritical with } \\
\text { visible blood }\end{array}$ \\
\hline $\begin{array}{l}\text { Low-level } \\
\text { disinfection }\end{array}$ & $\begin{array}{l}\text { Destroys most vegetative } \\
\text { bacteria and certain fungi and } \\
\text { viruses. Does not inactivate } \\
\text { Mycobacterium bovis. }\end{array}$ & $\begin{array}{l}\text { Liquid } \\
\text { contact }\end{array}$ & $\begin{array}{l}\text { EPA-registered hospital disinfectant with no label } \\
\text { claim regarding tuberculocidal activity. OSHA also } \\
\text { requires label claim of HIV and HBV potency for } \\
\text { use of low-level disinfectant for use on clinical } \\
\text { contact surfaces (e.g., quaternary ammonium } \\
\text { compounds, some phenolics, some iodophors) }\end{array}$ & $\begin{array}{l}\text { Noncritical without } \\
\text { visible blood }\end{array}$ \\
\hline
\end{tabular}




\section{Disinfection}

In a dental setup, surface equipment that does not contact the patient directly can become contaminated during treatment. Frequently touched surfaces like light handle, unit switches and drawer knobs can serve as reservoirs of microbial contamination. Transmission of infection from contaminated surfaces to patient occurs mainly by the hands of $\mathrm{HCP} \cdot{ }^{31,32}$ Routinelyformaldehyde fumigation of the dental setup will check such transmission.

$\mathrm{HCP}$ are responsible for cleaned and disinfected impression, appliance and materials prior to dispatch to the laboratory and should be disinfect according to the manufacture's recommendation. In 1992, H.S. Harold et $\mathrm{al}^{33}$ determined the efficacy of eight disinfectant solution: sodium hypochloride (undiluted), sodium hypochloride (diluted), Alcide L.D.,OMC II, Biocide, Sporicidin, Lysol, Impresept and sterile water (control) when used for immersion and a spray againstthree microorganism (S.aureus, M. Phlei and Bacillus subtilis) and normal mixed oral flora on the surface of irreversible hydrocollide impressions. This study concluded that, undiluted sodium hypochloride was the most effective disinfectant with shortest contact time (1 minute). Impression or appliance should be immersed in disinfectantinstead of spraying as it is less effective and caries the risk of inhalation. ${ }^{34}$ Prosthesis, inter treatment materials and non sterilizable equipment's if get contaminatedthen it will clean with soap and water and disinfected with a hospital level disinfectant. Impression arepreferred to disinfect as cast are most difficult to disinfect without causing damage. ${ }^{35-37}$ It is better to prevent contamination rather to use chemical agents over delicate equipment. ${ }^{38}$ Heat resistant items should be sterilized before use.

\section{Standard precautions}

Standard Precautions are designed to both protect healthcare professionals (HCP) and prevent HCP from spreading infections among patients. These practices are based on the principle that all body fluids pose a risk for blood borne virus transmission or may contain transmissible infectious micro-organisms. Body fluids include blood and body fluid, secretions, excretions (except sweat), non-intact skin and mucus membranes.

\section{Laboratory asepsis}

It is believe that infection control is not practice with full efficiency, some equipment need special attention even in clean laboratories. By this there may be less chance of laboratory contamination. Effective disinfectant solution should be added to the pumice solution. ${ }^{35}$ This will prevent the airborne colonization of microorganisms. Laboratory should be disinfected daily.Bench top, machines and work area should be cleaned daily. Same cleaning protocols should follow as it is practice in dental clinic. ${ }^{34}$

\section{Waste management}

BIOMEDICAL WASTE SEGREGATION:

Categories of biomedical waste includes:
CATEGORY 1-Human anatomical waste(human tissues, organs, body parts)-Incineration/deep burial
CATEGORY 2 - Animal waste(animal tissues, organs, body parts carcasses, bleeding parts, fluids, blood) -
Incineration/deep burial
CATEGORY 3-Microbiology \& biotechnology waste(waste from lab cultures, research and infectious agents
from research and industrial lab)-Incineration/deep burial
CATEGORY 4 - Sharps (needles, syringes, scalpel, blades, glass) - Incineration/disinfection
treatment/mutilation
CATEGORY 5-Medicines and cytotoxic drugs Incineration/destruction and Disposal in secured landfill
CATEGORY 6-Solid waste(blood and body fluids)autoclavel chemical treatment/burial
CATEGORY 7-Solid waste(disposable items) autoclave/ chemical treatment/burial
CATEGORY 8-liquid waste(waste generated from lab., and washing, cleaning, housekeeping \& disinfecting
activities)-disinfection/chemicals/ discharge into drains
CATEGORY 9-Incineration ash -disposal in municipal landfill
CATEGORY 10-Chemical waste-chemical treatment/ securelandfill

Bio medical waste segregation/ categories of biomedical waste includes

Biomedical waste is defined as any waste as the solid or liquid waste arising from health care or health related facilities. They are broadly categories as:

1. Non- infectious waste

2. Infectious waste 


\begin{tabular}{|c|c|c|c|}
\hline $\begin{array}{l}\text { COLOUR } \\
\text { CODING }\end{array}$ & $\begin{array}{c}\text { TYPE OF } \\
\text { CONTAINER }\end{array}$ & WASTE CATEGORY & $\begin{array}{c}\text { TREATMENT } \\
\text { OPTIONS }\end{array}$ \\
\hline YELLOW & Plastic bag & $\begin{array}{l}\text { Human anatomical } \\
\text { wastes, animal waste, } \\
\text { microbiology and bio- } \\
\text { technology wastes and } \\
\text { solid wastes }\end{array}$ & $\begin{array}{l}\text { Incineration/deep } \\
\text { burial }\end{array}$ \\
\hline RED & $\begin{array}{l}\text { Plastic } \\
\text { bag/disinfected } \\
\text { container }\end{array}$ & $\begin{array}{l}\text { Microbiology and bio - } \\
\text { technology wastes and } \\
\text { solid wastes }\end{array}$ & $\begin{array}{l}\text { Autoclaving/microwa } \\
\text { ve/chemical } \\
\text { treatment }\end{array}$ \\
\hline $\begin{array}{l}\text { BLUEMWHITE } \\
\text { TRANSLUCENT }\end{array}$ & $\begin{array}{l}\text { Plastic } \\
\text { bag/puncture } \\
\text { proof container }\end{array}$ & $\begin{array}{l}\text { Waste sharps and solid } \\
\text { wastes }\end{array}$ & $\begin{array}{l}\text { Autoclaving/microwa } \\
\text { ve/chemical } \\
\text { treatment/shredding }\end{array}$ \\
\hline BLACK & Plastic bag & $\begin{array}{l}\text { Discarded medicines, } \\
\text { incineration ash and } \\
\text { chemicals used in } \\
\text { production of biologicals }\end{array}$ & $\begin{array}{l}\text { Disposal in secured } \\
\text { landfill }\end{array}$ \\
\hline
\end{tabular}

\section{Spillage management}

Cleaning staff should respond quickly to spillage. Staff should wear personal protective equipment and immediately cover the area with paper and discard in yellow bag. Use $1 \%$ Sodium hypoclorite to mop the area followed by clean water. $^{41}$

\section{Precaution in dental radiology}

At the time of taking radiographs for patients, HCP should ensure that protective plastic cover the radiographic films or RVG sensors in order to prevent transmission to other patients and to prevent the contamination of processing equipment's. Gloves are used to release film onto clean area, position of film, holder and tube, selecting and taking exposure. Bite-blocks and holders are sterilizable.

\section{Conclusion:-}

Cross infection control is an essential aspect of dental practice. Assuming that all patients are carrier of disease, strict infection control should be done using universal standard precautions. This can be achieved by wholesome efforts of whole dental team. Cleaning should always preceded high-level disinfection and sterilization. Current disinfection and sterilization guidelines must be strictly followed.

\section{Reference:-}

1. Runnells RR (1988) An overview of infection control in dental practice. J Prosthet Dent 59: 625-629.

2. Samaranayake L (1993) Rules of infection control. Int Dent J 43: 578-584

3. Clare Connor. -Cross - contamination control in prosthodontic practicell. mt. J. Prosthodont, 1991; 4:337-344

4. Infection control recommendations for the dental office and the dental laboratory. J Am Dent Assoc 1992; Suppl: 1-8.

5. Recommended infection-control practices for dentistry, 1993. Centers for Disease Control and Prevention.

MMWR Recomm Rep 1993;42(RR-8):1-12.

6. Kohn WG, Collins AS, Cleveland JL, Harte JA, Eklund KJ,Malvitz DM. Centers for Disease Control and Prevention (CDC). Guidelines for infection control in dental health-care settings-2003. MMWR Recomm Rep 2003;52(RR-17):1-61

7. State, Brazil. J Public Health Dent 2006;66(4):282-4. de Souza RA, Namen FM, Galan J Jr, Vieira C, Sedano HO. Infection control measures among senior dental students in Rio de Janeiro 
8. Puttaiah R, Bedi R, Younblood D, Shulman J, Kohli A. Rationale for Dental Safety in Dental Infection Control and Occupational Safety for Oral Health Professionals, New Delhi, India: Indian Standards Published by the Dental Council of India; 2007. p. 2-8

9. Miller CH, Palenik CJ. Infection Control and Management of Hazardous Material for the Dental Team, 4 ed. United States of America: Mosby Elsevier; 2010.

10. Yengopal V, Naidoo S, Chikte UM. Infection control among dentists in private practice in Durban. SADJ 2001;56(12):580-4

11. Guidelines on AIDS and first aid in the work place. WHO AIDS series 1990; No. 7

12. Statement to fellows on HIV infection and AIDS. Royal College of Surgeons of Edinburgh, Edinburgh. 1990.

13. Guide to blood borne viruses and the control of cross infection in dentistry. British Dental Association, London. 1990.

14. Ananthnarayan, R. and Paniker, C. (2000). Textbook of Microbiology. $10^{\text {th }}$ ed. Chennai: Orient Longman, p.513.

15. Chiarello LA, Bartley J. Prevention of blood exposure in healthcare personnel. Seminars in Infection Control 2001;1:30-43.

16. Rosenberg JL, Jones DP, Lipitz LR, Kirsner JB. Viral hepatitis: an occupational hazard to surgeons. JAMA1973;223:395-400.

17. CDC. Immunization of health-care workers: recommendations of the Advisory Committee on Immunization Practices (ACIP) and the Hospital Infection Control Practices Advisory Committee (HICPAC). MMWR 1997;46(No. RR-18).

18. Steere AC, Mallison GF. Handwashing practices for the prevention of nosocomial infections. Ann Intern Med 1975;83:683-90.121.

19. Garner JS. CDC guideline for prevention of surgical wound infections, 1985. Supersedes guideline for prevention of surgical wound infections published in 1982. (Originally published in November 1985). Revised. Infect Control 1986;7:193-200.

20. Larson EL. APIC guideline for hand washing and hand antisepsis in health-care settings. Am J Infect Control 1995;23:251-69.

21. CDC. Guideline for hand hygiene in health-care settings: recommendations of the Healthcare Infection Control Practices Advisory Committee and the HICPAC/SHEA/APIC/IDSA Hand Hygiene Task Force. MMWR 2002;51(No. RR-16)

22. Maki DG, Alvarado CJ, Hassemer CA, Zilz MA. Relation of the inanimate hospital environment to endemic nosocomial infection. N Engl J Med 1982;307:1562--6.

23. Danforth D, Nicolle LE, Hume K, Alfieri N, Sims H. Nosocomial infections on nursing units with floors cleaned with a disinfectant compared with detergent. J Hosp Infect 1987;10:229—35.

24. Harrel SK, Molinari J. Aerosols and splatter in dentistry: a brief review of the literature and infection control implications. J Am Dent Assoc. 2004: (135)4;429-437.

25. Cochran MA, Miller CH, Sheldrake MS. The efficacy of the rubber dam as a barrier to the spread of microorganisms during dental treatment. J Am Dent Assoc 1989;119:141--4. (172)

26. CDC. Recommended infection-control practices for dentistry, 1993. MMWR 1993;42(No. RR-8).

27. Council on dental materials, instruments, and equipment, council on dental practice, council on dental therapeutics. - Infection control recommendations for the dental office and the laboratoryll. J. Am. Dent. Assoc., 1998; 116:241 -248.

28. Sherry. A. Harfst. -Personal barrier protection\|. D. C. N. A., 1991;35(2): 357 - 366.

29. Spaulding EH. Chemical disinfection of medical and surgical materials [Chapter 32]. In: Lawrence CA, Block SS, eds. Disinfection, sterilization and preservation. Philadelphia, PA: Lea \&Febiger, 1968:517--31.

30. Kohn WG, Collins AS, Cleveland JL, Harte JA, Eklund KJ, Malvitz DM. Guidelines for infection control in dental health-care settings-2003.MMWR. 2003;52(RR17):1-61.

31. Lowbury E. J. L, Lilly B. A, Ayliffe G. A. J. Preoperative disinfection of surgeons' hands: use of alcoholic solutions and effects of gloves on skin flora. Br Med J 1974; 4: 369-372.

32. Ugbam G. A. Comparative study of different scrubbing agents in surgical practice. West Afr J Med 1988; 5: 1319.

33. Harold.S.W, Donald V.B. andRichard S.S. "Efficacy of various spray disinfectants on irreversible hydrocolloid impressions". Tnt. J. Prosthodont., 1992; $5: 47$ - 54.

34. . Infection control recommendations for the dental office and the dental laboratory. ADA Council on Scientific Affairs and ADA Council on Dental Practice. J Am Dent Assoc 1996;127:672-80. 
35. RudraKaul. , Aamir Rashid Purra, Riyaz Farooq, ,ShafaitullahKhateeb, Fayaz Ahmad, Parvez Ahmed Parvez -Infection control in dental laboratories : a review - International Journal of Clinical Cases and Investigations 2012. Volume 4 (Issue 2), 19:32, 1st July 2012.

36. Dental laboratory relationship working Group OSAP Position paper. Laboratory Asepsis: November 1998.

37. Wood PR. Cross infection control in dentistry a practical illustrated guide.

38. Bhat Vidya S, Shetty Mallika S, ShenoyKamalakanth - Infection control in the prosthodontic laboratoryll Journal of Indian prosthodontic society Year : 2007| Volume : $7 \mid$ Issue : 2 | Page : 62-65.

39. Mills SE. The dental unit waterline controversy: defusing the myths, defining the solutions. J Am Dent Assoc 2000;131:1427-41

40. Rutala WA, Mayhall CG. Medical waste. Infect control hospEdidemiol 1992;13:38 --

41. CDC. Recommended infection-control practices for dentistry, 1993. MMWR 1993;42(No. RR-8). 